\title{
Pedagogical Content Knowledge: A Case Study of ESL Teacher Educator
}

\author{
Siping Liu $^{1}$ \\ ${ }^{1}$ College of Foreign Languages and Literature, Wuhan University, China \\ Correspondence: Siping Liu, Jianshe Dadao \#613, House 36-2, Wuhan, 430030, China. E-mail: \\ siping.liu@whu.edu.cn
}

Received: April 6, 2013 Accepted: May 7, 2013 Online Published: June 3, 2013

doi:10.5539/elt.v6n7p128 URL: http://dx.doi.org/10.5539/elt.v6n7p128

\begin{abstract}
This single-case study focuses on the pedagogical content knowledge (PCK) of a university faculty member teaching Second Language Acquisition to elementary teacher candidates. The research questions address the pattern and development of PCK for ESL teaching. Based on data from classroom observation, interviews and document review, the study finds that policy and culture are predominated parts in ESL teacher education, the early period contributes more constructively to the formation of PCK, and pedagogical knowledge plays a more active role in teaching ESL. The study suggests that ESL teacher education should provide standardized and easy-to-learn ESL pedagogical knowledge.
\end{abstract}

Keywords: pedagogical content knowledge, teaching TESL, university faculty

\section{Introduction}

For the last 20 years, pedagogical content knowledge (PCK) has been a focus of research in the literature of teacher knowledge (Magnusson, Krajcik \& Borko, 1999; Shulman, 1986). Findings yielded by the research of PCK help researchers deepen their understanding of teacher knowledge in specific areas such as mathematics (Marks, 1990) and science (Lee and Luft, 2008). They also help to professionalize teaching by setting standards in teacher education programs. For example, in the United States, the National Science Education Standards (National Research Council, 1996) integrates the concept of PCK as an important part of professional development for prospective science teachers (Lee \& Luft, 2008) and the Interstate New Teacher Assessment and Support Consortium (INTASC) also establishes standards of specialized teacher knowledge for beginning teachers. The standards are used for licensure in all subjects and have been recognized in more than 30 states in the United States (Darling-Hammond, 2006).

In the United States, due to growing number of immigrants, English as a second language (ESL) has always been an essential and important course for English language learners (ELL) and good English is a pathway to academic success and good job opportunities for ELL students (Ovando, Collier and Combs, 2003). Statistics shows that the number of English language learners in the U.S. public schools is on constant increase. In 2004-2005, approximately 5.1 million, covering 10.5 percent of U.S. student population, were ELL students (Payán and Nettles, 2006). However, in contrast to the huge number of English language learners, $73 \%$ of large urban school districts were in immediate need of ESL teachers (Hall, Quinn and Gollnick, 2008). Those who teach ESL feel frustrated and unconfident because of the lack of adequate professional knowledge (Karabenick and Noda, 2004). It is commonly recognized that teacher education is essential to develop teachers' knowledge and to prepare them for effective teaching (Grossman, 1990). However, a survey of the literature reveals little research on teacher knowledge and teacher education in the area of ESL. Due to the shortage of empirical studies in the literature of ESL dealing with teacher preparation, those who are involved in teacher education have little critical understanding about the education of ESL teachers (Freeman \& Johnson, 1998). To explore this rarely-studied area, my study intends to examine the knowledge of a teacher educator teaching ESL to teacher candidates. I believe that by examining and delineating the pattern and developmental process of the ESL educator's professional knowledge, my study can elicit more research on this area and eventually ESL teacher education will construct its own professional standards.

\section{Theoretical Bases}

I ground my study in the concept of pedagogical content knowledge, a type of knowledge exclusively used by 
teachers. Shulman $(1986,1987)$ posited that to accomplish effective teaching, teachers need to combine the subject and pedagogy so that they demonstrate "an understanding of how particular topics, problems, or issues are organized, represented, and adapted to diverse interests and abilities of learners, and presented for instruction" (Shulman, 1987, p. 8). In other words, in order to make knowledge understandable and teachable to students, teachers transform knowledge into forms of representations, analogies, illustrations, examples, explanations, and demonstrations (Shulman, 1986, p. 9). To transform knowledge, teachers need to apply several discrete categories of knowledge synergistically (Abell, 2008). These categories of knowledge include subject matter knowledge, pedagogical knowledge, knowledge of learners, and knowledge of teaching contexts (Fernandez-Balboa and Stiehl, 1995; Gess-Newsome and Lederman, 2001; Grossman, 1990). To illustrate, teachers first need to understand the subject she is teaching. In Shulman's words, a teacher's knowledge of biology may reasonably be expected to be equal to that of a non-teacher, layman or non-expert. Next, she knows how to teach biology as a subject, and she is also familiar with her students' cognitive understanding of biology. Finally, she is clear about the general educational environment where her teaching occurs such as the school, the community and the culture (Gess-Newsome, 1999).

Researchers (Park \& Oliver, 2008) believed that the categories as components of PCK are interrelated to each other to guarantee teachers' effective transformation of knowledge to learners. However, how these components are integrated and interact with each other is still a question that calls for empirical research, especially in ESL. For example, in ESL teaching practice, subject matter knowledge and pedagogical knowledge are often treated as separate categories and one category is emphasized by ignoring the other. On one hand, teaching English to ESL students is believed to be a kind of ability that every English native speaker is capable of because of their natural English competence developed by birth and geography (Freeman \& Johnson, 1998; Snow 1996). Thus, the identity of native English speaker may qualify a person to teach English because of his or her strong subject matter knowledge of natural English competence. However, ES teachers' assumed effectiveness in helping EFL students develop English competence, especially oral English competence, does not always match the reality and needs of English learners. Mcllwraith (1996) found that Chinese university students gave lower evaluation to their American NES teachers than to their Chinese non-NES English teachers. On the other hand, effective ESL teaching is viewed as the ability to implement a stock of strategies. For example, Communicative language Teaching (CLT) was once applauded as an effective approach to teach in different ESL and even English-as-foreign-language (EFL) contexts because it helps learners develop fluent use of English by involving them in accomplishing tasks in interactive ways (Maley, 1984). With this understanding of teaching English, teacher education is supposed to convey popular strategies to teacher candidates (Richards, 1990). In light of this assumption, language teaching is considered as "a kind of technology and the teacher educator's task is to get the teacher to perform according to certain rules" (Richards, 1990, p. 8).

To articulate from the perspective of PCK, the job of ESL teacher educators is to help preservice teachers develop the type of knowledge that is integrated with different components such as knowledge of English (subject matter knowledge) and knowledge of teaching English (pedagogical knowledge). In other words, teacher knowledge for ESL does not exclusively refer to subject matter knowledge or pedagogical knowledge. Based on this assumption, it is significant to explore the interactive relationship among different components of teacher knowledge, which is molded into PCK for effective ESL teaching to particular students in particular learning contexts.

Another point in teacher knowledge is the assumption that experienced teachers have well-formed PCK and PCK is developed and shaped through years of teaching experience (Clermont, Borko \& Krajcik, 1994). To recognize the claim that PCK grows out of teaching experience rather than formal education, the role of teacher education seems to be dwarfed in preparing qualified new teachers. Freeman and Johnson (1998) claimed that "the true locus of teacher learning lay on-the job initiation into the practice of teaching and not in the processes of professional teaching education" (p. 399). Actually, it has always been debated about how knowledge of teaching is acquired, whether from formal teacher education programs or teaching experience (Grossman, 1990). Due to its uniqueness, to address the issue in ESL will deepen and extend debate. In essence, teaching ESL is different from teaching other subjects. The subject matter knowledge of ESL is not clearly defined. The knowledge may be either viewed as phonology, morphology, syntax, applied linguistics, and theories of second language acquisition (SLA) or the practical knowledge contributed by experienced teachers in teacher training programs (Reid, 1995/1996). The reason for the ambiguity lies in the fact that English as subject matter is "an accident of birth and geography" for NES teachers (Freeman \& Johnson, 1998, p. 404). As native English speakers, the preservice teachers' natural English acquisition experiences have established their initial cognitions about teaching and learning English, and they conceptualize ESL teaching based on these cognitions while they are 
receiving teacher education (Borg, 2003). In addition, the natural acquisition empowers NES teachers to decide by themselves the construct of the knowledge (Freeman \& Johnson, 1998). In light of the natural advantage of teaching English, researchers (e.g., Freeman \& Johnson, 1998) argue that teacher educators are responsible to clearly define the forms of knowledge on which the profession of ESL is based. To define teacher knowledge for ESL teaching, I find it necessary to examine what knowledge ESL teacher educators have and how they develop the knowledge.

\section{Literature Review}

In contrast to the argument that effective teachers are built on experience (Clermont, Borko \& Krajcik, 1994), research on ESL teachers and teaching demonstrates that ESL teachers suffer from weak professional development. For example, Karabenick and Noda (2004) surveyed 729 teachers from a U.S. urban school district in which one third of its student population was identified as ELL students. The teachers who were surveyed expressed a pervasive need to develop their professional knowledge and teaching skills in teaching ELL students. However, how to teach ELL teachers also proves difficult because few systematic studies in the literature are available regarding the process of teaching ESL (Richards, 1990). The consequence is that ESL teachers teach by intuition and common sense (ibid). Eisenstein-and Schweers (1997) found from a survey of 30 ESL teachers in New York and 30 from Puerto Rico that their participants seldom referred to research findings or theories to justify their selection of certain approaches in teaching grammar. Jones (2002) also noticed that preservice teachers were not prepared for teaching ELL students. He investigated 91 preservice teachers and found that they knew little about second language teaching. He noticed a sharp contrast between the preservice teacher's prior experience and the real situations they would encounter when they began to teach. For example, most U.S. preservice teachers registered in teacher education program were white and came from middle class families, and they had little personal experience with ELL learners, who are most often immigrant children and speak another language at home. In addition, many preservice teachers didn't expect that they would teach ELL students in their class and therefore they paid little attention to it during their teacher education (Jones, 2002). But the truth was that ELL students were growing fast in mainstream classes, especially by the end of 1990's when bilingual programs were deemphasized in the United States. Because teachers were not trained for ESL teaching, they felt at a loss how to teach ELL students (Mora, 2000).

It was the same case in the United States 10 years ago. According to U.S. National Center for Education Statistics (1999), 54\% teachers in American public schools had ELL students in their classes but only $20 \%$ of them believed that they were well prepared to teach them. It is also the case in other countries where English is taught as a second language. For example, a survey of 146 ESL trainees in Hong Kong indicates that the ESL teacher candidates believe that second language learning should primarily center on vocabulary and grammar (Peacock, 2001). These situations are inevitably mounting pressure upon teacher education for more well-prepared ESL teachers.

In the United States, with the policy of No Child Left Behind (NCLB) taking effect, states are required to identify ELL students and assess their English proficiency, and they are also expected to use the assessments of ELL students in determining Adequate Yearly Progress (AYP). Besides, according to NCLB, "highly qualified teachers" is one of the important mandates which set higher standards for teacher candidates. Under this situation, teacher education programs are facing new challenges to update and reform the curriculum in ESL teacher education. However, in the literature, scholars always hold contradictory theories in ELL education. Some scholars (e.g., Cochran-Smith, 1997; Darder, 1991; González \& Darling-Hammond, 1997; Ladson-Billings, 1994; Snow, 2000) believe that teachers should be prepared in culturally responsive pedagogy for effective ELL teaching. They believe that additive acculturation is a model that can foster bilingualism and biculturalism so as to ensure quality education for ELL students (Gibson, 1995). Some others (e.g., Clark, 1999; Porter, 1999-2000; Rossell, 1998) who advocate assimilationist pedagogy assume that English should be the only language of instruction for ELL students and the exclusive use of English will help them to grow out of the dependence upon their first language and also help them to achieve success at school and in society. This debate will be more significant when it is grounded in the study of the knowledge and beliefs of ESL teacher educators because they are the very people that help to form and develop the knowledge structure of ESL teachers (Grossman, 1990).

However, the literature is still short of sufficient research on ESL teachers' professional knowledge. The few articles addressing ESL teacher knowledge only focus on one part such as writing (Sengupta, Xiao, Maida, 2002), grammar (Johnson \& Karin, 2000), pedagogical knowledge (Gatbonton, 1999) or comparative study between ESL teachers and regular class teachers (Constantino, 1994). Considering the fact that teacher knowledge exerts great influence on teachers' classroom actions (Grossman. 1990), it is necessary to explore it so as to paint a 
clear picture of what ESL teacher knowledge looks like as it has been done in other subjects. Because teacher education makes formative contribution to the development of what teachers know (Grossman, 1990), higher education institutions are responsible to develop qualified and competent teachers (Cochran-Smith, 2003). The responsibility finally rests on teacher educators, who are "now the linchpins in educational reforms of all kinds" (Cochran-Smith, 2003, p. 5). In the United States, for example, if teachers are better prepared in teacher education program, they will cope better with the situation of the increasingly growing ELL student population in the public schools (Ladson-Billings, 1996).

My study addresses the issue of the ESL teacher educator in terms of professional knowledge, i.e., the pedagogical content knowledge for teaching ESL preservice teachers. To address the issues, I explore the following three questions:

(1) What is the general pattern of the ESL teacher educator's PCK?

(2) How does the ESL teacher educator develop his PCK?

(3) What component of PCK for ESL teaching is more active?

The first research question intends to find what part of content knowledge is predominant, whether the content knowledge is dominated by English knowledge or teaching skills. A study of this kind addresses the argument about what should be taught in ESL classroom. The second question addresses the debate about the usefulness of teacher education. ESL teachers are native English speakers and whether they still need professional education to teach English and how they develop expertise in ESL teaching are significant questions for ESL teacher education. The third question is concerned with the special case in my study, a teacher educator teaching ESL theories to NES teacher candidates. For such a teacher, whether he is supposed to demonstrate teaching as a craft or teach ESL theories as a subject (Richards, 1990) is a question that ESL teacher educators always face.

\section{Methodology, Data Collection and Analysis}

The case in my research was a university faculty member, teaching SLA to 14 elementary teacher candidates. SLA, as a course, is the study of "the process by which people develop proficiency in a second or foreign language" (Richards, Platt \& Platt, 2000, p. 407). SLA is usually a mandatory course for ESL teacher candidates (Gass \& Selinker, 2001) because it establishes "the theoretical basis for the practical components of teacher education program" (Richards, 1990, p. 3). The participant is an experienced teacher who has been involved in ESL education for 28 years. He teaches SLA for the purpose of preparing the teacher candidates with necessary ESL knowledge. I selected him as my case for the following reasons. First, because of his many years of teaching ESL to both adult students and teacher candidates, it is assumed that he had developed a strong PCK (Lee, Brown, Luft, \& Roehrig, 2007). This type of knowledge is regarded as experiential knowledge developed through classroom experience (Baxter \& Lederman, 1999; Gess-Newsome, 1999; Grossman, 1990) and in turn experienced teachers apply it in their teaching (Barnett, 2001). Next, with his experience of teaching different types of students, he teaches more effectively because experienced teachers are believed to be good at using learning experiences for particular students and in particular learning contexts (Magnusson, Krajcik and Borko, 1999). Therefore, he has potential value to demonstrate expertise in teaching that can "guide the focus and design of pre-service and in-service teacher education programs" (Magnusson et al, 1999, p. 116).

Because PCK is complex in nature and it is difficult to capture its construct (Magnusson et al, 1999), I implemented triangulation by collecting data from multiple sources so that I could analyze the same data from various perspectives for higher validity (Yin, 2003). The first method was participant classroom observation. In particular, I shadowed the course 3 hours each week for a whole semester. Such close and constant observation offered an in-depth look at the participant's knowledge and beliefs, which are usually considered to be personal, practical and tacit (Baxter \& Lederman, 1999; Tsui, 2003). However, because teachers may select only a few from an array of their representations for a particular subject matter in class performance (Kagan, 1990), I also used interview. Because my case study of PCK is descriptive rather than prescriptive, I employed both structured questions for in-depth interview and unstructured questions for informal interview. The structured questions I developed were partly based on observation, a common practice in qualitative research (Glesne, 2006), and partly based on theories concerning ESL. I also asked questions in the informal interview after my observation of a particular class, especially during the early stage of my observation when I tried to get more information to formulate questions for subsequent in-depth interview (Merriam, 1988). In designing the interview questions, I took into consideration the fact that the participant in my case study taught to the students as teachers. Because teachers develop their professional knowledge through formal teacher education as well as from their experience in real classroom teaching and learning (Grossman, 1990), I included interview questions concerning how my participant took his students and the context into account in planning his lessons and also I observed how he tried 
to inculcate the conceptions of being a teacher to the teacher candidates. The third method was document review. The documents to be reviewed included syllabus, the reading materials assigned by the participant to the students, books read aloud in the class, handouts distributed in the class, posters the students wrote as assignments, teaching aids and video tapes. By analyzing the documents, I obtained information that could more objectively reflect the participant's understanding of ESL as a subject, teaching strategies, knowledge of students and the teaching contexts (Glesne, 2006).

The data collected were first categorized according to different categories of PCK, i.e., subject matter knowledge, pedagogical knowledge, knowledge of learners, and knowledge of teaching contexts. I then wrote a list of codes and selected those relevant to my research questions. In analyzing the data I also referred to the standard of ESL established by the organization of Teachers of English to Speakers of Other Languages (TESOL), "a global association for English language teaching professionals (TESOL, 2007). TESOL (2007) established the first ESL standard for K-12 ESL education in the United States. Because the participant in my case study teaches ESL to preservice elementary teachers, this standard applies to his situation.

\section{Findings}

\subsection{Importance of ELL Policy and Culture}

The course the participant taught was Theories of Second Language Learning. The 14 students he taught were all Americans whose first language was English. They joined an elementary school teacher education program and eventually they would become elementary teachers teaching general subjects in elementary schools. The course of Second Language Acquisition was one of the courses that made up of the whole curriculum for the students. According to the syllabus, the participant intended to cover six areas, namely, the federal and the state English language learning policy, cross-cultural communication and understanding, applied linguistics and second language acquisition, methods \& techniques in teaching English as a second language, curriculum development and adaptation, and language assessment. For these six areas, the participant put on different weight. For the 12-week course of teaching, he set aside four weeks for ESL policies and culture. The topic for the first class was ELL policy. The participant began his class by creating a situation where children with low English proficiency would encounter: they sit through classes together with children whose first language is not English. They are afraid of asking questions and feel ignored. To reinforce the idea of equality of educational right for ELL learners, the participant also introduced an important case "Lau v. Nichols", which is a legal case ruled by the US Supreme Court in favor of ELL students' equal right of education. The participant explained that he gave priority to policy and law because ESL teaching in the United States was defended by policy and law. Because of the nature of American schools where a lot of students' primary language was not English and because such children usually attended mainstream classes with their native English peers to learn math, science and social studies, teachers had to modify their content to meet the special needs of these English language learners. So the theories of second language acquisition had to be connected with law and policy.

For the subsequent three classes, the participant devoted his attention to culture, i.e. culture in society, culture in school and cultural issues for teaching and learning. The beginning of the cultural session was unique: each student was given either a green or a while sheet of paper with a message on it. Each tried to find a partner who had a conflicting message. After each student found their partner, they read the message to annoy the other. Each pair argued from their own cultural perspective. Then the participant talked about the respect for different cultures in terms of language and he also distributed reading materials. One of them read:

Each people have their own tongue

So they can speak and discuss with their own words.

Listen, children, we do too.

When we have something to say,

We say it in our own words,

The same way our fathers spoke with their fathers.

Tell me, which language is better than ours?

I'll tell you - there is not one language.

There are no words

More beautiful than our own.

As he was explaining culture in society, he asked them to contribute to their understanding of culture. The 
students' response compiled a long list---social rules, ethnicity, religion, behavior, beliefs, food and language. What the participant tried to convey was the respect for different cultures and cultural diversity either at school or in the society at large. On the next class when he covered culture at school, he held a group discussion on the following three questions: 1) How might home and community culture affect the life of kids in school? 2) What societal expectation about U.S. school culture causes obstacles for kid whose backgrounds may be different from that of the school administration? 3) How can such differences in cultural attitude be accommodated with the school environment? Besides classroom teaching about culture, the participant also assigned an interview as homework for his students to accomplish. He asked the students to interview an adult 'whose native/first language was not English and whose native/first culture was_not mainstream of U.S and did not share the same cultural background'. In answering my questions regarding the relationship between culture and ESL, the participant justified his emphasis on culture. One of the primary reasons was the context in American schools, where teachers would meet kids of immigrants whose first language and culture were not English.

\subsection{Teaching Strategies and Techniques}

Besides culture, another major topic the participant addressed was theories of second language acquisition. At the beginning of each class, he would inevitably start his class by reading a novel or a poem. For example, on the first class to teach the theories of second language acquisition, he read a novel by an Iran writer. The story narrates a child's dilemma of living in a bilingual world, speaking half her father's Arabic and half her British mother' English. The story depicts a picture of the child torn by two languages and cultures in her family. In another class, the participant read three poems selected from the Dream on Blanca's Wall written by Jane Medina, who tells how a young girl becomes a teacher and how her "expressive bilingual poetry conveys the inner feelings of a young Latina growing up in a barrio where she must learn English". Besides reading stories, the participant also played stories. In one of the classes, he played the video of 'story of English', a film depicting how Afro-Americans influenced on American English and what remnants are still part of American English today. When asked why he always began a class with novel reading, he explained that story reading was an effective way of warming-up, getting the students to think and guiding them to the direction of second language acquisition. The selection was also related closely to the issue the students would be working with. For example, the participant read three poems describing a school girl who was an English language learner, and they showed a reality in the immigrant families in America: how English learning powers kids and dispowers adults. When children learn to speak English, they are able to communicate and settle business for their families while their parents feel helpless due to the weakness in English.

In the class of ESL theories, the participant simplified the theories into basic linguistic knowledge. He spent almost two thirds of the time explaining every English phoneme. He exaggerated his presentation dramatically by showing how to pronounce each consonant and vowel such as voiceless $/ \mathrm{k} /$ and voiced $/ \mathrm{g} /$. On the wall the participant hung up three posters on the three sides of the wall and each showed phonological terms such as bilabial, labiodentals, alveolar, velar, glottal, plosive, fricative, affricate, and nasal, etc. He asked each student to pick up two pieces of papers bearing phonemes like $/ \mathrm{k} /$ and $/ \mathrm{g} /$ and match the phonemes in their hands under the right phonological terms on the posters and the students moved around in the class to paste their answers under the three posters. In teaching semantics, the participant presented some sentences with misplaced words such as "what is your favorite disease?", "I've got a colorless ideas" and "He sleeps furiously". He then asked the students to sense how words were structured and to find what the logical word was. As for the reasons why he focused on the elaboration of simple linguistic knowledge, he simply replied that because these students were native English speakers and they were like the fish who didn't know water was wet. They used English everyday and they were not aware of their mother tongue. What he was trying to do is to take them out of the water of English to help them realize the 'wet water'.

When the participant set examples, he usually used Spanish, which he spoke quite fluently. He told me in the interview that he spent his childhood in Miami, Florida, where Spanish was spoken as the first language and he studied Spanish linguistics for his bachelor degree. Because most of his practical experience was in Spanish, he used a lot of Spanish in his teaching.

\section{Discussion}

The research questions I raised for this case study are (1) What is the general pattern of the ESL teacher educator's PCK? (2) How does the ESL teacher educator develop his PCK? (3) What component of PCK for ESL teaching is more active? According to my findings I came up with the following answers. I analyzed the findings according to the criteria used in the study of PCK in general, i.e. the four categories of PCK: subject 
matter knowledge, pedagogical knowledge, knowledge of learners and knowledge of context.

To address the first question of the general pattern of PCK in ESL, I found the participant combined language theories and practice together. He made it clear that he had two major objectives in mind: knowledge and skill. The students were expected to gain awareness of linguistic aspects of their own teaching, and to pay close attention to language they used as tool and then to be able to modify their teaching, their planning, activities, to make language accessible to all students. The participant believed that the objectives of teaching ESL are professional in the field, which are teachers' standards and they come from the field of TESL. He consulted the standards of TESOL when he wrote the syllabus for the course because, in his words, all the syllabi in ESL education in the United States include TESOL standards. However, it was found that ESL teachers were not restricted by syllabus and they taught according to their theoretical beliefs, and differences in theoretical beliefs might lead to differences in the nature of instruction (Richards \& Lockhart, 1994). Likewise, the participant admitted that he reordered the standards according to his understanding of ESL: teaching applied linguistics that links to the application of classrooms. Such flexible understanding and application of ESL theories are not rare cases. Researchers in second language acquisition also noticed that theories of ESL were detached from reality. Markee (1997) noticed that a gap separated theories and practice and "most potential consumers of SLA research are frequently repelled by its disregard for real world issues" (p. 88). As a result, Krashen concluded that theory was "rejected by most language teachers" (Krashen, 1983, p. 255). However, from my findings, theories were actually modified according to the teacher's understanding developed from practical teaching. The participant majored in linguistics in both bachelor and master degrees. He clearly stated that he did refer to theories but what he intended to teach was more practical skills and less theoretical knowledge. His selection of the content to teach was based on his knowledge of the students and their teaching context. He emphasized the importance of language experience approach, which, as he explained, is knowledge that ESL teachers need to have so as to understand and eventually use language experience approach as a way of making the content they teach accessible for learners. He also prioritized culture and policy because teaching ESL students was closely related to policies such as equality. This issue is more important than teaching English. He told me that the first thing he did when he came to teach ESL in this university was to read through all the state policies and laws in the state where the university is located. He added that if he had taught in China, he would have pay less attention to policy as Chinese are monolinguals and China has centralized educational system.

The participant demonstrated PCK quite flexibly or in Krashen's words, divorced from theories. However, in essence, his approach to teaching ESL reflects his understanding of SLA theories, i.e., always connecting language teaching to the real people. His approach also matches the ESL standards set by TESOL, i.e. teaching language for communication and developing language in cultural, social, and cognitive processes. This indicates that in ESL teaching flexibility is based on patterns and rules. ESL theories are retreated to the background which is hardly noticeable when different pedagogical activities dominate in the classroom. In other words, it is formal education and strong knowledge of linguistic theories that enable ESL teachers to be flexible.

Regarding the development of his PCK, the participant said that besides the formal education, his expertise was more actively supported by his experience, deriving from his own teaching, workshops, and "very knowledgeable colleagues", especially when he started teaching. He was lucky to have a "very very good mentor", who was doing a workshop by using music to teach when the participant met her. In his words, her workshop was so compelling and informative that he could take it immediately to his own class. Mentoring laid a foundation that helped him to invent, borrow and adapt different activities that he implemented in his classes just as Wang \& Odell (2002) point out that "teacher mentoring is effective in developing novices' management skills, solving their immediate problems in organizing and disciplining students" (p. 496). As far as subject matter knowledge in teaching ESL is concerned, the participant acquired it from both formal and informal channels. However, judged by his teaching experience, his understanding of the students and the teaching situation, he revised the knowledge. So in terms of the development of PCK for ESL teaching, my findings are consistent with other researchers who believe that PCK is experiential knowledge and skills that teachers acquire in their teaching experience (Baxter \& Lederman, 1999; Gess-Newsome, 1999; Grossman, 1990). However, from my findings I draw two conclusions. First, formal education lays the foundation for variety in using ESL teaching methods. Second, the critical phase for ESL teachers to develop PCK is the early period. During the early period novice teachers begin to cross the border from a student as a teacher to a teacher as a student and their cognition is open to be shaped because they "are responsible for making instructional decisions based upon the learning of their students and the established standards" (Lee, Brown, Luft, \& Roehrig, 2007, p. 57). The participant cherished the fond memory of his mentor and his colleagues when he started teaching and how he immediately applied his observations to his own class. While researchers found that development of PCK takes 
time (ibid), no studies ever noticed the critical period over the length of PCK development. I argue that the critical time is the early period when preservice teachers begin to change their role from preservice students to inservice teachers.

For the third question "what component of PCK for ESL teaching is more active", I found that pedagogical knowledge plays a more active role than any other components of PCK such as subject matter knowledge, knowledge of students and context. The participant depicted a rich repertoire of strategies and techniques typical of language instruction. He always arranged the seating in a circle with the students sitting around facing each other, and it was convenient for them to ask and answer questions. He used a variety of teaching aids such as toys, colored paper and posters. Besides, he often read aloud a story to begin his class to guide the students to experience the real meaning of language and he organized different activities and tasks. While the students engaged in them, he would stand by and give occasional support. Clay (1991) suggests that ESL teachers should adopt various approaches to provide opportunities for different learning, to encourage students to speak, think, and learn, to raise critical questions while listening, and to act as a back-up resources and support system. Just as the participant said, he helped the students build a little bit of teaching strategies by demonstration and he wanted the students to understand and eventually use them in their teaching. He believed that his activities were very useful for language learning universally. Darling-Hammond (2005) defined effective teachers as "diagnosticians and planners who understand the learning process and have a large repertoire of teaching methods at their disposal (p. 3). This is true of the participant in ESL teaching. Compared with his pedagogical knowledge, his subject matter knowledge played a relatively static role. The subject matter knowledge he demonstrated is the standard of TESOL and theories of SLA. McEwan \& Bull (1991) suggested that "different learners must travel different routes to the same, or similar, destinations" (p. 327), i.e., the subject matter knowledge. In the same vein, teachers may also present different strategies that help learners to achieve the goal. This indicates that pedagogical knowledge is the most active catalyst that sets off change in learning. Grossman, Reynolds, Ringstaff, and Sykes (1985) also argued that subject matter knowledge is universal but pedagogical knowledge is idiosyncratic. When Lee, Brown, Luft, \& Roehrig (2007) found that novice teachers demonstrated limited level of PCK despite their strong science knowledge background, they strongly recommended that courses of how to teach science be included in the curriculum.

The participant also took the students and teaching context into consideration. He reiterated in my interview that teachers need to know how to modify their content in order to meet the needs of all students, especially English language learners. He was also aware that the teacher candidates were native English speakers, and so he taught them phonology and semantics in a way that could help them realize how English as a language really functions. Because the students would eventually teach in elementary schools, a teaching context where they would most probably meet ELL children from immigrant families, the participant attached a lot of attention to the cultural diversity at school and managed to arouse the students' concern on cultural issues. However, compared with pedagogical knowledge, these components are less active as they are knowledge that teachers need to acquire over time. Lee and Luft (2008) introduced a core PCK that even novice teachers are supposed to have developed: subject matter knowledge, knowledge of instructional purposes and knowledge of learners. In the core PCK, pedagogical knowledge is not included. This indicates that pedagogical knowledge is experientially and dynamically acquired in practical teaching whereas knowledge needed to understand students can be learned early in teacher education programs.

\section{Conclusion}

PCK, as a type of knowledge that is exclusive of teachers (Shulman, 1987), develops when teachers gain experience in real classroom teaching. Over the period of its development, the early phase is critical. If this is true, beginning teachers need more professional guidance in forms such as mentoring, observation of colleagues' classes and public lessons (Wang and Paine, 2003). What is more important for ESL teacher education is the professionalization or standardization of pedagogical knowledge. According to my findings, pedagogical knowledge is the most active component in PCK but it is also less controllable and teachable. As a result, ESL teachers teach English without much professional justification (Richards, 1990). Because the flexible use of teaching strategies is acquired through experience as well as from formal education, how to effectively convey teaching strategies to teacher candidates is a question that should be addressed. If teacher candidates acquire teaching skills in teacher education program, they may only need to hone them in real classroom teaching rather than learn them from scratch (Richards, 1990; Grossman, 1990). Here I argue that in ESL teacher education pedagogical knowledge is the type of knowledge that should be acquired through several sources such as constant observation, active mentoring and inservice teaching. Meanwhile, one cannot ignore the role of formal education in teaching pedagogical knowledge. If the development of pedagogical knowledge is exclusively 
developed from experience, ESL teaching will be highly personalized. Therefore, it is necessary to standardize ESL pedagogical knowledge and make it teachable to ESL teacher candidates. Based on formal education, they need to observe and practice so as to internalize the pedagogical knowledge and play it automatically. Furthermore, licensure and assessment should be also based on standardization, especially for elementary teachers because their requirements of subject matter knowledge are quite basic but their teaching strategies make a great difference for children.

\section{Limitations}

My case study only focuses on one teacher engaged in ESL teaching, and therefore it is difficult to generalize, as is also the case for most single case studies (Glesne, 2006). Besides, because of the nature of PCK, it is difficult to identify its components with clear boundaries (Gess-Newsome, 1999). My observational data are also not complete as the teacher may employ only a small part of his accumulation of PCK for teaching the course (Baxter \& Lederman, 1999). Another difficulty is that analyzing PCK is time-consuming to develop, administer, and analyze (Kagan, 1990).

\section{References}

Abell, S. (2008). Twenty Years Later: Does pedagogical content knowledge remain a useful idea? International Journal of Science Education, 30, 1405-1416. http://dx.doi.org/10.1080/09500690802187041

Baxter, J. A., \& Lederman, N. G. (1999). Assessment and measurement of pedagogical content knowledge. In Gess-Newsome, J. (Ed.), Examining Pedagogical Content Knowledge: The Construct and its Implications for Science Education (pp. 147-161). Dordrecht: Kluwer Academic Publishers.

Barnett, J. (2001). Pedagogical context knowledge: Toward a fuller understanding of what good science teachers know. Science Teacher Education, 85, 426-453.

Borg, S. (2003). Teacher cognition in language teaching: A review of research on what language teachers think, know, believe, and do. Language Teaching, 36, 81-109. http://dx.doi.org/10.1017/S0261444803001903

Clark, K. (1999). Fromprimary language instruction to English immersion: How five California districts made the switch. Washington, DC: READ (Institute for Research in English Acquisition and Development).

Clermont, C. P., Borko, H., \& Krajcik, J. S. (1994). Comparative study of the pedagogical content knowledge of experienced and novice chemical demonstrators. Journal of Research in Science Teaching, 31, 419-441. http://dx.doi.org/10.1002/tea.3660310409

Cochran-Smith, M. (1997). Knowledge, skills, and experiences for teaching culturally diverse learners: A perspective for practicing teachers. In J. J. Irvine (Ed.), Critical knowledge for diverse teachers and learners (pp. 27-88). Washington, DC: American Association of Colleges of Teacher Education.

Cochran-Smith, M. (2003). Learning and unlearning: the education of teacher educators. Teaching and Teacher Education, 19, 5-28. http://dx.doi.org/10.1016/S0742-051X(02)00091-4

Constantino, R. (1994). A study concerning instruction of ESL students comparing all-English classroom teacher knowledge and English as a Second Language teacher knowledge. Journal of Educational Issues of Language Minority Students, 13, 37-57.

Darder, A. (1991). Culture and power in the classroom. Westport, CT: Bergin \& Garvey.

Darling-Hammond, L. (2006). Assessing Teacher Education: The Usefulness of Multiple Measures for Assessing

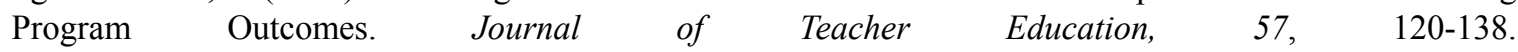
http://dx.doi.org/10.1177/0022487105283796

Freeman, D., \& Johnson, K. (1998). Reconceptualizing the knowledge-base of language teacher education. TESOl Quarterly, 32, 397-417. http://dx.doi.org/10.2307/3588114

Gatbonton, Elizabeth. (1999). Investigating Experienced ESL Teachers' Pedagogical Knowledge. Modern Language Journal, 83, 35-50. http://dx.doi.org/10.1111/0026-7902.00004

Gass, S. M., \& Selinker, L. (2001). Second Language Acquisition: An Introductory Course (Second edition). Mahwah, NJ: Lawrence Erlbaum Associates.

Gess-Newsome, J. (1999). Pedagogical content knowledge: an introduction and orientation. In J. Gess-Newsome, \& N. G. Lederman (Eds.), PCK and Science Education (pp. 3-17). Netherlands: Kluwere Academic Publishers.

Glesne, C. (2006). Becoming qualitative researchers: an introduction. Boston: Pearson Education Inc. 
González, J. M., \& Darling-Hammond, L. (1997). New concepts for new challenges: Professional development for teachers of immigrant youth. McHenry, IL: Center for Applied Linguistics.

Grossman, P. L. (1990). The making of a teacher: Teacher knowledge and teacher education. NY: Teachers College Press.

Johnston, B., \& Goettsch, K. (2000). In Search of the Knowledge Base of Language Teaching: Explanations by Experienced Teachers. Canadian Modern Language Review, 56, 437-468. http://dx.doi.org/10.3138/cmlr.56.3.437

Jones, T. G. (2002). Preparing all teachers for linguistic diversity in K-12 schools. Repors-research (143) Speeches/Meeting Papers (150).

Kagan, D. M. (1990). Ways of evaluating teacher cognition: Inferences concerning the Goldilocks Principle. Review of Educational Research, 60(3), 419-469. http://dx.doi.org/10.3102/00346543060003419

Karabenick, S. K., \& Noda, P. C. (2004). Professional development implications of teachers' beliefs and attitudes toward English language learners. Bilingual Research Journal, 28(1), 55-75. http://dx.doi.org/10.1080/15235882.2004.10162612

Kennedy, M. (1991). An agenda for research on teacher learning (National center for research on teacher learning special report). East Lansing: Michigan State University.

Kleinasser, R., \& Savignon, S. (1992). Linguistics, language pedagogy, and teachers' technical cultures. In J. E. Alatis (Ed.), Georgetown University Round Table on Languages and Linguistics: Linguistics and language pedagogy: The state of the art (pp. 289-301). Washington, DC: Georgetown University Press.

Krashen, S. D., \& Terrell, T. D. (1983). The natural approach:Language acquisition in the classroom. Hayward, CA: Alemany Press.

Hall, G. E., Quinn, L. F., \& Gollnick, D. M. (2007). The Joy of Teaching: Making a Difference in Student Learning. Boston: Pearson Education, Inc.

Ladson-Billings, G. (1994). The dreamkeepers: Successful teachers of African American children. San Francisco: Jossey-Bass.

Lee, E., Brown, M., Luft, J. A., \& Roehrig, G. (2007). Assessing beginning secondary scienceteachers' PCK: Pilot year results. School Science and Mathematics, 107(2), 418-426. http://dx.doi.org/10.1111/j.1949-8594.2007.tb17768.x

Lee, E., \& Luft, J. (2008). Experienced secondary science teachers' representation of pedagogical content knowledge. International Journal of Science Education, 30(10), 1343-1363. http://dx.doi.org/10.1080/09500690802187058

Magnusson, S., Krajcik, J., \& Borko, H. (1999). Nature, sources, and development of pedagogical content knowledge for science teaching. In Gess-Newsome, J. (Ed.), Examining Pedagogical Content Knowledge: The Construct and its Implications for Science Education. Dordrecht: Kluwer Academic Publishers.

Markee, N. (1997). Second language acquisition research: A resource for changing teachers' professional cultures? Modern Language Journal, 81(1), 80-93. http://dx.doi.org/10.1111/j.1540-4781.1997.tb01628.x

Marks, R. (1990). Pedagogical content knowledge: From a mathematical case to a modified conception. Journal of Teacher Education, 41(3), 3-11. http://dx.doi.org/10.1177/002248719004100302

Marshall, C., \& Rossman, G. B. (2006). Designing qualitative research. Thousand Oaks, CA: Sage Publications.

McEwan, H., \& Bull, B. (1991). The pedagogic nature of subject matter knowledge. American Educational Research Journal, 28(2), 316-334. http://dx.doi.org/10.3102/00028312028002316

McIlwraith, H. (1996). Managing conflict in ATTC projects. ELT newsletter: Teaching English in China, 27, 103-107.

Mora, J. (2000). Staying the course in times of change, Preparing teachers for language minority education. Journal of Teacher Education, 51(5), 345-357. http://dx.doi.org/10.1177/0022487100051005003

National Center for Education Statistics. (1999). Teacher quality: A report on the preparation and qualifications of public school teachers. Retrieved from http://nces.ed.gov/pubs99/1999080.htm

Ovando, C. J., Collier, V. P., \& Combs, M. C. (2003). Bilingual and ESL Classrooms: Teaching in Multicultural Contexts. NY: McGraw-Hill. 
Park, S., \& Oliver, J. S. (2008). Revisiting the Conceptualisation of Pedagogical Content Knowledge (PCK): PCK as a Conceptual Tool to Understand Teachers as Professionals. Research science education, 38, 261-284. http://dx.doi.org/10.1007/s11165-007-9049-6

Payan, R. M., \& Nettles, M. T. (2008). Current state of English-Language learners in the U.S. K-12 student population. 2008 English Language Learner Symposium, Princeton, NJ. Retrieved October 2008, from http://www.ets.org/Media/Conferences_and_Events/pdf/ELLsympsium/ELL_factsheet.pdf

Peacock, M. (2001). Pre-service teachers' beliefs about second language learning: A longitudinal study. System, 29, 177-195. http://dx.doi.org/10.1016/S0346-251X(01)00010-0

Porter, R. P. (1999-2000). The benefits of English immersion. Educational Leadership, 57(4), 52-56.

Reid, J. M. (1995/1996, December/January). Let's put the "T" back in TESL/TEFL programs. TESOL Matters, 3.

Richards, J. C. (1990). The dilemma of teacher education in second language teaching. In Richards, J. C., \& Nunan, D. (Eds.), Second Language Teacher Education. Cambridge: Cambridge University Press.

Richards, J. C., Platt, J., \& Platt, H. (2000). Longman Dictionary of Language Teaching \& Applied Linguistics. Beijing: Foreign Language Teaching and Research Press.

Rossell, C. (1998). Declaration, United States District Court, Northern District of California, San Francisco. Valeria G. v. Wilson (Case No. C98-2252 1998, July 15).

Sengupta, S., Xiao, K., \& Maida. (2002). The Contextual Reshaping of Beliefs About L2 Writing: Three Teachers' Practical Process of Theory Construction. TESL-EJ, 6(1).

Short, P. (1997). ESL standards: Preface. Retrieved from http://www.tesol.org/s_tesol/sec_document.asp?CID=113\&DID=309

Shulman, L. S. (1986). Those who understand: Knowledge growth in teaching. Educational Research, 15(2), 4-14.

Shulman, L. S. (1987). Knowledge and teaching: Foundations of the new reform. Harvard Educational Review, $57(1), 1-22$.

Snow, D. (1996). More than a native speaker: An introduction for volunteers teaching abroad. Alexandria, VA: TESOL.

Snow, M. A. (Ed.). (2000). Implementing the ESL standards for pre-K-12 students through teacher education. Alexandria, VA: Teachers of Speakers of Other Languages.

Teachers of English to Speakers of Other Languages (TESOL). (2007). What is TESOL? Retrieved from http://www.tesol.org/s_tesol/bin.asp?CID=709\&DID=401\&DOC=FILE.PDF

Tsui, A. B. M. (2003). Understanding expertise in teaching Case Studies of ESL teachers. Cambridge: Cambridge University Press. http://dx.doi.org/10.1017/CBO9781139524698

Wang, J., \& Odell, S. J. (2002). Mentored learning to teach according to standards-based reform: A critical review. Review of Educational Research, 72(3), 481-546. http://dx.doi.org/10.3102/00346543072003481

Yin, R. K. (2003). Case study research: Design and methods (3rd ed.) Thousand Oaks, CA: Sage.

\section{Copyrights}

Copyright for this article is retained by the author(s), with first publication rights granted to the journal.

This is an open-access article distributed under the terms and conditions of the Creative Commons Attribution license (http://creativecommons.org/licenses/by/3.0/). 